\title{
FIRST RECORD OF OXYCARENUS LAVATERAE (FABRICIUS, 1787) (HETEROPTERA, LYGAEIDAE) IN TURKEY
}

\author{
ARSLANGÜNDOĞDU, Z. ${ }^{*}$ - HIZAL, E. - ACER, S. \\ Department of Forest Entomology and Protection, Faculty of Forestry, University of Istanbul \\ Istanbul, Turkey \\ *Corresponding author \\ e-mail:zeynel@istanbul.edu.tr \\ (Received $7^{\text {th }}$ Nov 2017; accepted $20^{\text {th }}$ Feb 2018)
}

\begin{abstract}
In autumn of 2017, Oxycarenus lavaterae (Hemiptera: Heteroptera: Oxycarenidae) was observed on linden trees (Tilia tomentosa) in a park in Sariyer, Istanbul, northwestern Turkey. This is the first record of this species from Turkey.
\end{abstract}

Keywords: Hemiptera, Oxycarenidae, Tilia tomentosa, invasive, Istanbul

\section{Introduction}

Oxycarenus lavaterae (Fabricius, 1787) (Heteroptera: Lygaeidea: Oxycarenidae) is widely distributed in Western Mediterranean region of Europe (Péricart, 1998, 2001). It occurs from northwest Africa to Portugal, southern Spain, southern France, southern Germany, Italy, Slovenia and Croatia (Velimirovic et al., 1992; Kalushkov, 2000; Rabitsch and Adlbauer, 2001; Wermelinger et al., 2005). During the last 20 years, $O$. lavaterae continued to spread eastwards into the Balkan Peninsula and northwards to the central Europe (Figure 1) (Velimirovic et al., 1992; Kondorosy, 1995; Bianchi and Stehlik, 1999; Protic and Stojanovic, 2001; Rabitsch and Adlbauer, 2001; Deckert, 2004; Wermelinger et al., 2005; Kment, 2009; Kment et al., 2006; Rabitsch, 2008, 2010; Hebda and Olbrycht, 2016). O. lavaterae spread to the east of Mediterranean area and can be found in Saudi-Arabia and Yemen as well as in tropical Africa to South Africa (Rabitsch and Adlbauer, 2001). Mass increase of O. lavaterae was previously observed and reported from and near Italy. Already in 1906 an exceptional infestation took place near the Lago Maggiore, Varese. In the same area, similarly Péricart (1998), and Dioli (1993) reported a massive increase of the population of the bug.

Oxycarenus lavaterae is a phytophagous insect native to the Western Mediterranean. The species has several known host plants, most of them belonging to Malvales. The species associated are members of plant family Malvaceae and Tiliaceae. Oxycarenus lavaterae sucks on green plant parts (e.g. leaves and unhindered shoots). In infested areas, most records originate from planted Tilia cordata trees in suburban and urban habitats (Rabitsch, 2008). When appearing in abundance, these bugs can cause damage in weakening linden trees, hence they are considered as insects with an economic importance (Velimirovic et al., 1992; Wachmann et al., 2007).

Depending on the temperature, multiple generations are produced each year. In their natural distribution area in Southern Europe, three to four generations are observed (Wermelinger et al., 2005; Kalushkov et al., 2007a; Simov et al., 2012; Nedvěd et al., 2014). They are encountered frequently on single trees and collect in masses on linden trees in autumn and spring (Wermelinger et al., 2005; Kalushkov, 2000). The bug winters in the form of larger or smaller agglomerations. They typically take shelter in 
sun exposed bark creaks on trunk and branches, and overwinter as adult; however, rarely few larvae are noticed (Bărbuceanu and Nicolaescu, 2012). Most animals are likely to endure winter in the rind of old linden trees, and therefore the mortality rate is high due decrease of shelter for the winter.

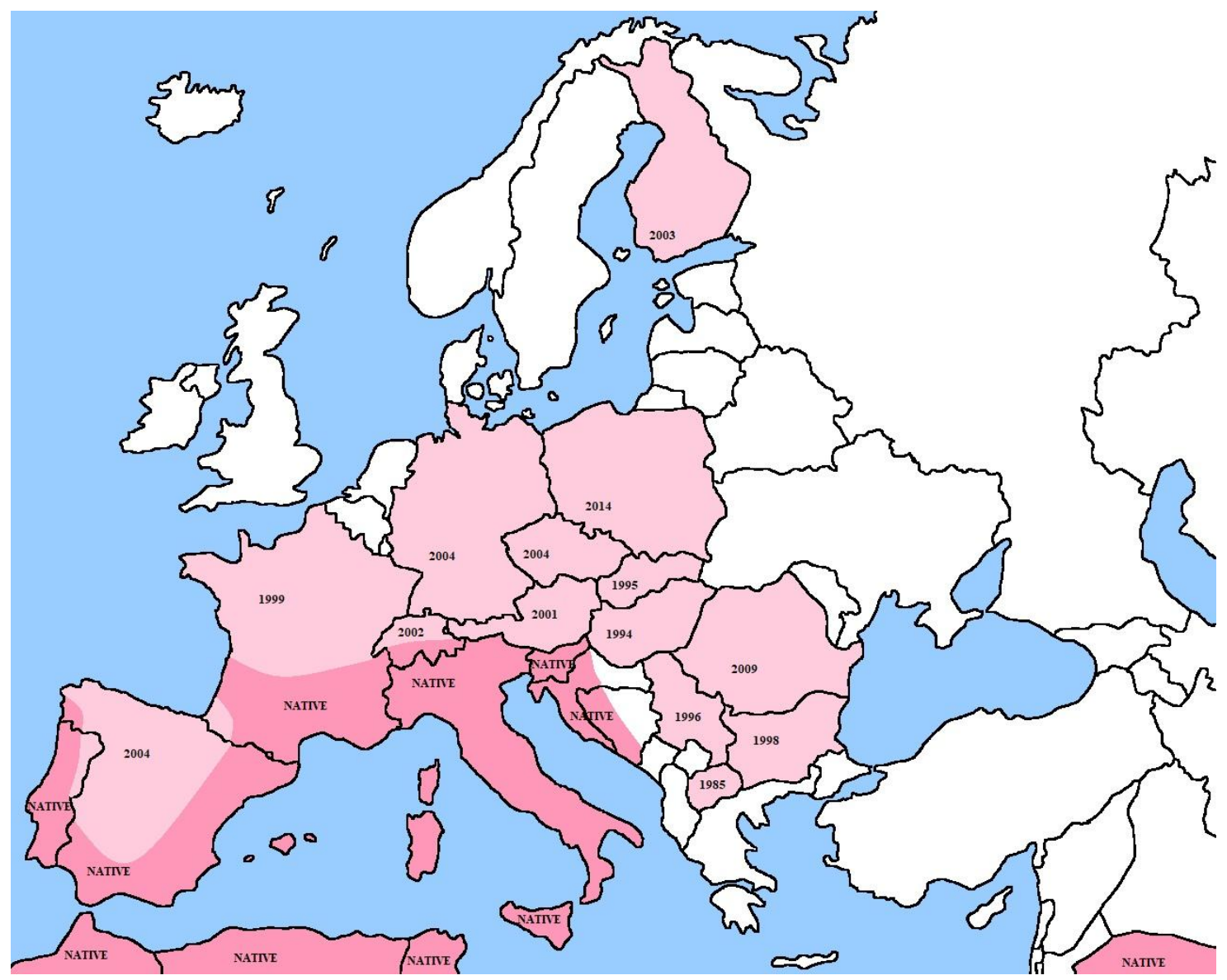

Figure 1. Distribution of O. lavaterae (Fabricius, 1787)

\section{Material and methods}

Our sampling area was located in "15 Temmuz Hatıra Ormanı" located in Garipce, Sariyer Istanbul, $\left(41^{\circ} 12^{\prime} \mathrm{S}, 2^{\circ} 5^{\prime} \mathrm{W}\right)$, northwestern Turkey. The park mostly consists of shrubs, pseudo shrubs and Pinus nigra trees. Very recently (May 2017), 250 sycamore and 82 linden trees (Tilia tomentosa) were planted. These trees were imported from Italy and Spain. Several dead linden trees were noticed by the park superintendent. Site was visited in September-October 2017. Insect colonies, which consisted of nymphs and adult insects, were located on trunks of several linden trees. Samples were collected in plastic containers with the help of thin brushes and transferred to laboratory for identification. Samples were examined with Leica stereomicroscope and photographs were taken. Body lengths were measure from the tip of the anterior to the posterior edge of the dorsal plater under the stereomicroscope. Insects were identificated using online identification keys and literature (e.g. Péricart, 1998; Costas et al., 1997). Representative samples were preserved as biological museum materials in the insect collection of the Istanbul University Forest Entomology and Protection. 


\section{Results and discussion}

The insect was identified as Oxycarenus lavaterae. It was found on in the field studies carried out in September-October 2017, the insects were identified on four of the trees and they were found to be in adult stage mostly as nymphs (Figure 2). The morphological description and size were similar to the reports. Our specimens' size were between $4.5-5.4 \mathrm{~mm}$ in adult females, of $4.2-5 \mathrm{~mm}$ in males. Nymphen stages have monochrome red hind whips. The nymphs can be easily recognized by their black head, black wing bads and the red-coloured abdomen. Adult animals show the typical red-black drawing on the wings, which is similar to that of the fire bug or the cinnamon bug. The front wings are colourless and transparent and reach the top of the abdomen or are a little longer. The head, antennae, the throat (Pronotum) and the sign (Scutellum) of the bug are coloured black. The hemipedema (hemielytren) are red to reddish brown and the wing membrane is bright.
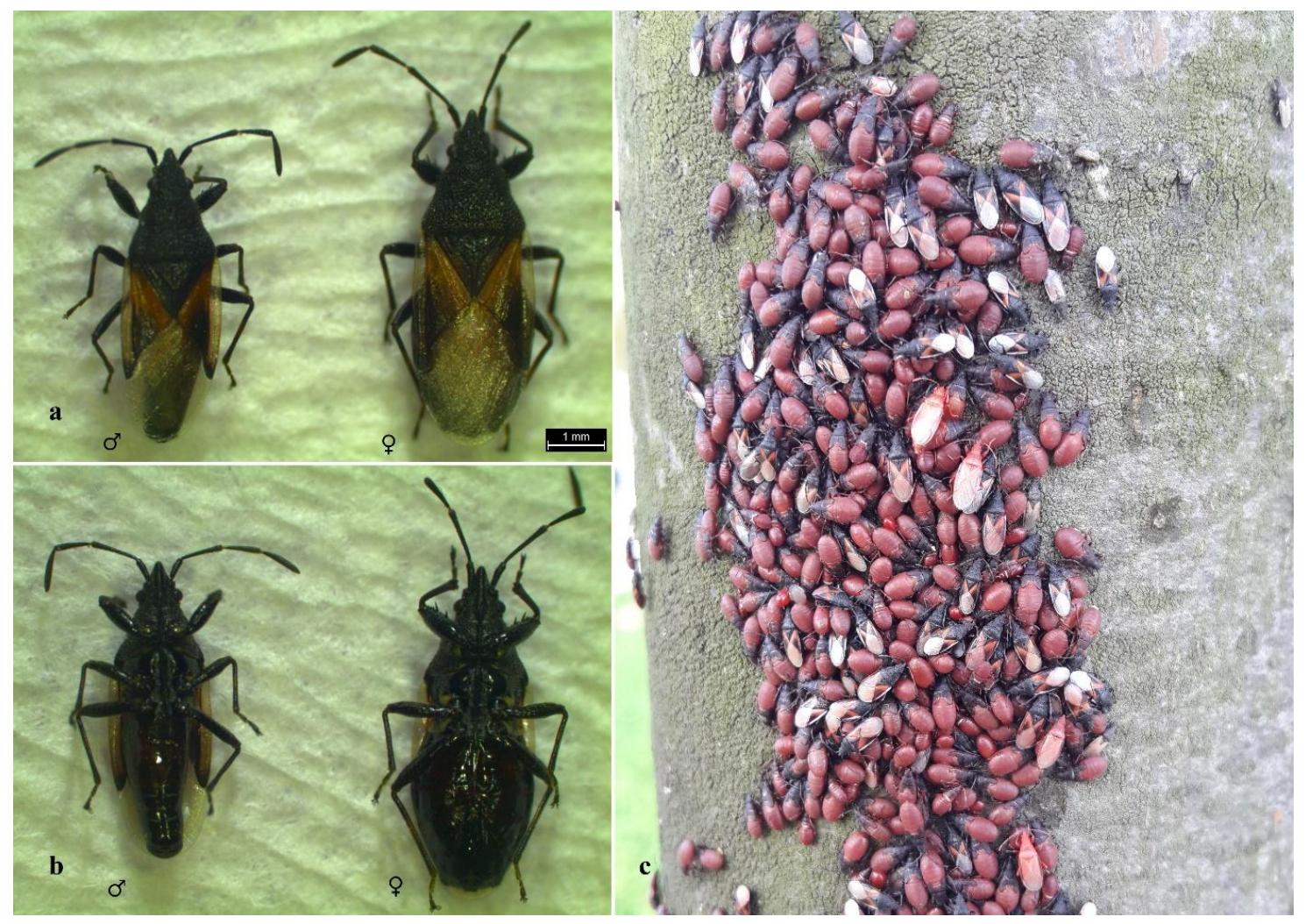

Figure 2. Oxycarenus lavaterae a) Top view. b) Bottom view. c) On the linden tree as a group

Several plant species were reported as host of the O. lavaterae in which all life stages were encountered (Table 1). In the park, we only encountered the insect on Tilia tomentosa, a host that is widely reported (Table 1).

Four species of the genus Oxycarenus Fiber, 1837 in Turkey is known including Oxycarenus hyalinipennis (Costa, 1847) (Lodos et al., 1999; Çağatay, 1985; Önder et al., 2006; Şerban, 2010; Küçükbasmac1 and Kıyak, 2015; Yazıc1 et al., 2015); Oxycarenus longiceps Wagner, 1954 (Lodos et al., 1999; Çağatay, 1985; Önder et al., 2006; Küçükbasmacı and Kıyak, 2015); Oxycarenus modestus (Fallén, 1829) (Lodos et al., 1999; Önder et al., 2006); and Oxycarenus pallens (Herrich-Schäffer, 1850) (Önder 
and Adıgüzel, 1979; Lodos et al., 1999; Çağatay, 1985; Kıyak et al., 2004; Önder et al., 2006; Matocq and Özgen, 2010; Yazıc1 et al., 2015; Fent and Dursun, 2016). To our knowledge, O. lavaterae was never reported from Turkey.

Table 1. Known host plants of the Oxycarenus lavaterae

\begin{tabular}{|c|c|c|}
\hline \multicolumn{2}{|c|}{ Plants } & \multirow{2}{*}{ References } \\
\hline Scientific name & Common name & \\
\hline Alcea sp., Alcea rosea & Hollyhock & $\begin{array}{l}\text { Stichel, 1958; Péricart, 1998; Wermelinger et al., 2005; } \\
\text { Kment et al., 2006; Rabitsch, } 2008\end{array}$ \\
\hline Althaea sp. & & Velimirovic et al., 1992; Wachmann et al., 2007 \\
\hline Althaea officinalis & Marsh mallow & Callot, 2016 \\
\hline Citrus sp. & & Wermelinger et al., 2005 \\
\hline $\begin{array}{l}\text { Citrus sinensis var. } \\
\text { clemenules }\end{array}$ & Sweet orange & Ribes et al., 2004 \\
\hline Corylus sp. & & Kalushkov, 2000; Rabitsch and Adlbauer, 2001 \\
\hline Corylus avellana & Corkscrew hazel & $\begin{array}{l}\text { Frey-Gessner, 1863, 1865; Péricart, 1998; Wermelinger } \\
\text { et al., 2005; Kment et al., 2006; Rabitsch, } 2008\end{array}$ \\
\hline Cynara scolymus & Globe artichoke & Stichel, 1958; Rabitsch and Adlbauer, 2001 \\
\hline Geranium sp. & & Stichel, 1958; Rabitsch and Adlbauer, 2001 \\
\hline Geranium sanguineum & Bloody cranesbill & Otto, 1996 \\
\hline Geranium sylvaticum & Wood cranesbill & Otto, 1996 \\
\hline Gossypium sp. & & $\begin{array}{l}\text { Ciampolini and Tremtera, 1987; Ferrer, 1996; Alvorado } \\
\text { et al., 1998; Wermelinger et al., 2005 }\end{array}$ \\
\hline Helianthus annuus & Sunflower & Kalushkov and Nedvěd, 2010 \\
\hline Hibiscus sp. & & $\begin{array}{l}\text { Stichel, 1958; Velimirovic et al., 1992; Wachmann et al., } \\
\text { 2007; Callot, } 2016\end{array}$ \\
\hline Hibiscus syriacus & Rose of Sharon & Kalushkov and Nedvěd, 2010 \\
\hline Lagunaria patersonii & Primrose tree & $\begin{array}{l}\text { Péricart, 1998; Wermelinger et al., 2005; Kment et al., } \\
\text { 2006; Rabitsch, 2008; Borges et al., } 2013\end{array}$ \\
\hline Lavatera sp. & & $\begin{array}{l}\text { Velimirovic et al., 1992; Kalushkov, 2000; Rabitsch and } \\
\text { Adlbauer, 2001; Wachmann et al., } 2007\end{array}$ \\
\hline Lavatera cretica & Cornish mallow & Cuesta Segura et al., 2010 \\
\hline Lavatera olbia & Tree mallow & $\begin{array}{l}\text { Péricart, 1998; Wermelinger et al., 2005; Kment et al., } \\
\text { 2006; Rabitsch, } 2008\end{array}$ \\
\hline Malva sp., Malva sylvestris & Common mallow & $\begin{array}{l}\text { Ciampolini and Tremtera, 1987; Ferrer, 1996; Alvorado } \\
\text { et al., } 1998\end{array}$ \\
\hline Platanus acerifolia & London plane & Hebda and Olbrycht, 2016 \\
\hline Populus sp. & & Goula et al., 1999; Rabitsch and Adlbauer, 2001 \\
\hline Prunus sp. & & $\begin{array}{l}\text { Ciampolini and Tremtera, 1987; Ferrer, 1996; Alvorado } \\
\text { et al., 1998; Wermelinger et al., } 2005\end{array}$ \\
\hline Sterculia sp. & & Ciampolini and Trematerra, 1986 \\
\hline Tilia sp. & & $\begin{array}{l}\text { Velimirovic et al., 1992; Kalushkov, 2000; Rabitsch and } \\
\text { Adlbauer, 2001; Wachmann et al., } 2007\end{array}$ \\
\hline Tilia cordata & Little-leaf linden & $\begin{array}{l}\text { Velimirovic et al., 1992; Kalushkov et al., 2007a/b; } \\
\text { Kalushkov and Nedvěd, 2010; Seward et al., 2017; } \\
\text { Simov et al., } 2012\end{array}$ \\
\hline Tilia platyphyllos & Broad-leaved linden & Schneider and Dorow, 2016; Seward et al., 2017 \\
\hline Tilia parvifolia & Small-leaved linden & Kalushkov et al., 2007a/b \\
\hline Tilia rubra & Large-leaved linden & Kalushkov et al., 2007a/b \\
\hline $\begin{array}{l}\text { Tilia tomentosa } \quad(=\text { Tilia } \\
\text { argentea })\end{array}$ & Silver linden & $\begin{array}{l}\text { Kalushkov et al., 2007a/b; Kalushkov and Nedvěd, 2010; } \\
\text { Simov et al., } 2012\end{array}$ \\
\hline Triticum vulgare & Wheat & Kalushkov and Nedvěd, 2010 \\
\hline Vitis sp. & & $\begin{array}{l}\text { Ciampolini and Tremtera, 1987; Ferrer, 1996; Alvorado } \\
\text { et al., 1998; Wermelinger et al., 2005 }\end{array}$ \\
\hline
\end{tabular}


O. lavaterae was reported from Bulgaria in 1998 and subsequent spread appears to be towards western European countries. Because it was encountered for the first time on imported trees, it is highly likely that they have not spread into Turkey. Oxycarenus lavaterae are invasive insects (Kalushkov and Nedvěd, 2010; Putchkov, 2013; Nedvěd et al., 2014; Hebda and Olbrycht, 2016). In particular, on weakened trees these bugs can be found in massive groups and cause the death. The four infested trees died and were removed from the park in an effort to eradicate the insects. Even though $O$. lavaterae is not very harmful (Reynaud, 2000; Ribes et al., 2004; Simov et al., 2012), they have the potential to spread to many parts of Turkey because linden trees are commonly planted in parks and recreational areas in Turkey.

\section{REFERENCES}

[1] Alvorado, M., Duran, J. M., Serrano, A., de la Rosa, A., Ortiz, E. (1998): Contribucion al conocimiento de las chinches (Heteroptera) fitofagas del algodon en Andalucia Occidental. - Boletin de Sanidad Vegetal Plagas 28: 817-828.

[2] Bărbuceanu, D., Nicolaescu, D. P. (2012): Pest of ornamental trees and shrubs in the parks of Pitesti and methods of fighting them. - Current Trends in Natural Sciences 1(1): 2-5.

[3] Bianchi, Z., Stehlik, J. L. (1999): Oxycarenus lavaterae (Fabricius, 1787) in Slovakia (Heteroptera: Lygaeidae). - Acta Musei Moraviae, Scientiae Biologice 84: 203-204.

[4] Borges, P. A. V., Reut, M., da Ponte, N. B., Quartau, J. A., Fletcher, M., Sousa, A. B., Pollet, M., Soares, A. O., Marcelino, J. A. P., Rego, C., Cardoso, P. (2013): New records of exotic spiders and insects to the Azores, and new data on recently introduced species. Arquipelago: Life and Marine Sciences 30: 57-70.

[5] Callot, H. (2016): Quelques observations de pullulations d'Hétéroptères. - Bulletin De La Société Entomologique De Mulhouse en Alsace 72(1): 6-14.

[6] Ciampolini, M., Tremtera, P. (1987): Biological studies on Oxycarenus lavaterae (F.) (Heteroptera, Lygaeidae). - Bollettino di Zoologia Agraria e di Bachicoltura, Serie II, 19: 187-197.

[7] Costas, M., Vázquez, M. A., López, T. (1997): Sobre las especies del género Oxycarenus Fieber, 1837 (Heteroptera, Lygaeidae) de la Península Ibérica. - Zool. baetica 8: 5-17.

[8] Cuesta Segura, D., Baena Ruiz, M., Mifsud, D. (2010): New records of terrestrial bugs from the Maltese Islands with an updated list of Maltese Heteroptera (Insecta: Hemiptera). - Bulletin of the Entomological Society of Malta 3: 19-39.

[9] Çağatay (Aysev), N. (1985): Türkiye Oxycareninae (Heteroptera-Lygaeidae) Alt Familyasının Taksonomisi ve Erkek Genital Organının Önemi Üzerine Çalışmalar. Bitki Koruma Bülteni 25(1-2): 18-29.

[10] Deckert, J. (2004): Zum Vorkommen von Oxycareninae (Heteroptera, Lygaeidae) in Berlin und Brandenburg. - Insecta (Berlin) 9: 67-75.

[11] Dioli, P. (1993): Eterotteri insubrici ed eterotteri xerotermici nei territori perilacustri della Lombardia e del Ticino (Hemiptera, Heteroptera). - Memorie Soc. Ticinese Sci. Nat. 4: 81-86.

[12] Fent, M., Dursun, A. (2016): Beiträge zur Lygaeidae-Fauna (Hemiptera: Heteroptera) des Westlichen Schwarzmeer-Gebietes in der Türkei. - Heteropteron 47: 30-36.

[13] Ferrer, M. M. (1996): La nueva plaga del melocoton precoz en las Islas canarias: Danos, reconocimiento y control. - Phytoma Espana 79: 27-32.

[14] Frey-Gessner, E. (1863): Zusammenstellung der durch Meyer-Dür im Frühling im Tessin und Anfang Sommer 1863 im Ober-Engadin beobachteten und gesammelten Hemiptern und Orthoptern. - Mitteilungen der Schweizerischen Entomologischen Gesellschaft 1: $150-154$. 
[15] Frey-Gessner, E. (1865): Verzeichnis schweizerischer Insekten (Fortsetzung aus Heft 7). - Mitteilungen der Schweizerischen Entomologischen Gesellschaft 1: 304-310.

[16] Goula, M., Espinosa, M., Eritja, R., Aranda, C. 1999: Oxycarenus lavaterae (Fabricius, 1787) en Cornelia de Llobregat (Barcelona, Espana) (Heteroptera, Lygaeidae). - Bulletin de la Société entomologique de France 104(1): 39-43.

[17] Hebda, G., Olbrycht, T. (2016): Oxycarenus lavaterae (Fabricius, 1787) (Hemiptera: Heteroptera: Oxycarenidae) - a new species to the fauna of Poland. - Poznań Entomological News 35(3): 133-136.

[18] Kalushkov, P. (2000): Observations on the biology of Oxycarenus lavaterae (Fabricius) (Heteroptera: Lygaeidae), a new Mediterranean species in the Bulgarian fauna. - Acta Zoologica Bulgarica 52: 13-15.

[19] Kalushkov, P., Nedvěd, O. (2010): Suitability of Food Plants for Oxycarenus lavaterae (Heteroptera: Lygaeidae), a Mediterranean Bug Invasive in Central and South-East Europe. - Comptes rendus de l'Academie bulgare des Sciences Tome 63(2): 271-276.

[20] Kalushkov, P., Simov, N., Tzankova, R. (2007a): Biology and Acclimatization of Oxycarenus lavaterae (Heteroptera: Lygaeidae) a New Invasive Mediterranean Species in Bulgarian Fauna. - In: Ninov, N. (ed.) Proceedings of the International Conference 'Alien Arthropods in South East Europe - Crossroad of Three Continents', pp. 44-47. University of Forestry, Sofia.

[21] Kalushkov P., Simov, N., Tzankova, R. (2007b): Laboratory and field investigation on the biology of Oxycarenus lavaterae (Fabricius) (Heteroptera: Lygaeidae) in Bulgaria. Acta Zoologica Bulgarica 59(2): 217-219.

[22] Kiyak, S., Özsaraç, Ö., Salur, A. (2004): Additional Notes on the Heteroptera fauna of Nevşehir province (Turkey). - Gazi Univ J Sci 17: 21-29.

[23] Kment, P. (2009): Oxycarenus lavaterae, an expansive species new to Romania (Hemiptera: Heteroptera: Oxycarenidae). - Acta Musei Moraviae, Scientiae Biologicae 94: 23-25.

[24] Kment, P., Vahala, O., Hradil, K. (2006): First records of Oxycarenus lavaterae (Fabricius, 1787) (Heteroptera: Oxycarenidae) from the Czech Republic with review of its distribution and biology. - Klapalekiana 42: 97-127.

[25] Kondorosy, E. (1995): Oxycarenus lavaterae a new lygaeid species in the Hungarian bug fauna (Heteroptera: Lygaeidaee). - Folia Entomologica Hungarica 56: 237-238 (in Hungarian, English abstr.).

[26] Küçükbasmac1, İ., Kıyak, S. (2015): A study on the fauna of Heteroptera of Ilgaz Mountains (Kastamonu, Çankırı) with a new record for Turkey. - Nevşehir Bilim ve Teknoloji Dergisi 4(1): 1-33.

[27] Lodos, N., Önder, F., Pehlivan, E., Atalay, R., Erkin, E., Karsavuran, Y., Tezcan, S., Aksoy, S. (1999): Faunistic studies on Lygaeidae (Heteroptera) of Western Black Sea, Central Anatolia and Mediterrannean regions of Turkey, pp. ix + 58. - Ege University, İzmir.

[28] Matocq, A., Özgen, İ. (2010): Preliminary list of Heteroptera collected in Mardin and Siirt Provinces from South-Eastern Anatolia of Turkey (Hemiptera). - Mun. Ent. Zool. 5: 1011-1019.

[29] Nedvěd, O., Chehlarov E., Kalushkov P. (2014): Life history of the invasive bug Oxycarenus lavaterae (Heteroptera: Oxycarenidae) in Bulgaria. - Acta Zoologica Bulgarica 66(2): 203-208.

[30] Otto, A. (1996): Die Wanzenfauna montaner Magerwiesen und Grünbrachen im Kanton Tessin (Insecta: Heteroptera). Eine faunistisch-ökologische Untersuchung. - Diss. ETH Zurich, Nr. 11457.

[31] Önder, F., Adıgüzel, N. (1979): Some Heteroptera collected by light trap in Diyarbakır (Turkey). - Türkiye Bitki Koruma Dergisi 3(1): 25-34.

[32] Önder, F., Karsavuran, Y., Tezcan, S., Fent, M. (2006): Türkiye Heteroptera (Insecta) Kataloğu. (Heteroptera (Insecta) Catalogue of Turkey). - Meta Basım Matbaacılık, İzmir. 
[33] Péricart, J. (1998): Hémiptères Lygaeidae euro-méditerranéens. Vol. 2. Faune de France, 84B, i-iii. - FFSSN, Paris.

[34] Péricart J. (2001): Family Lygaeidae Schilling, 1829 - Seed Bugs. - In: Aukema B, Rieger, C (eds.) Catalogue of the Heteroptera of the Palaearctic Region, pp. 35-220. The Netherlands Entomological Society, Wageningen.

[35] Protic, L., Stojanovic, A. (2001): Oxycarenus lavaterae (Fabricius, 1787) (Heteroptera: Lygaeidae) another new species in the entomofauna of Serbia. - Protection of Nature (Beograd) 52: 61-63 (in Serbian, English summary).

[36] Putchkov, P. V. (2013): Invasive true bugs (Heteroptera) established in Europe. Український Ентомологічний Журнал (Ukrainian Entomological Magazine) 2(7): 1128.

[37] Rabitsch, W. (2008): Alien true bugs of Europe (Insecta: Hemiptera: Heteroptera). Zootaxa 1827: 1-44.

[38] Rabitsch, W. (2010): True Bugs (Hemiptera, Heteroptera). - In: Roques, A., Kenis, M., Lees, D., Lopez-Vaamonde, C., Rabitsch, W., Rasplus, J. Y., Roy D. (eds). Alien Terrestrial Arthropods of Europe, pp. 407-433, Chapter 9.1. BioRisk 4. Pensoft Publishers, Sofia.

[39] Rabitsch, W., Adlbauer, K. (2001): Erstnachweis und bekannte Verbreitung von Oxycarenus lavaterae (Fabricius, 1787) in Österreich (Heteroptera: Lygaeidae). Beiträge zur Entomofauna 2: 49-54.

[40] Reynaud, P. (2000): Bug Oxycarenus lavaterae responsible for extraordinary infestations in Paris. - Phytoma, La défense des végétaux 528: 30-33 (in French).

[41] Ribes, J., Piñol, J., Espadaler, X., Cañellas, N. (2004): Heterópteros de un cultivo ecológico de cítricos de Tarragona (Cataluña, NE España) (Hemiptera: Heteroptera). Orsis 19: 21-35.

[42] Schneider, A., Dorow, W. H. O. (2016): Erstnachweis von Oxycarenus lavaterae (Fabricius, 1787) für Hessen. - Heteropteron 45: 23-24.

[43] Seward, E. A., Votýpka, J., Kment, P., Lukeš, J., Kelly, S. (2017): Description of Phytomonas oxycareni n. sp. from the Salivary Glands of Oxycarenus lavaterae. - Protist 168: 71-79.

[44] Simov, N., Langourov, M., Grozeva, S., Gradinarov, D. (2012): New and interesting records of alien and native true bugs (Hemiptera: Heteroptera) from Bulgaria. - Acta Zoologica Bulgarica 64(3): 241-252.

[45] Stichel, W. (1958): Illustrierte Bestimmungstabelle der Wanzen. II. Europa, pp. 97-224. Hemiptera-Heteroptera Europae 4. - Stichel, Berlin-Hermsdorf.

[46] Şerban, C. (2010): Faunistic data on some true bugs species (Insecta: Heteroptera) from West Turkey. [Results of the "Taurus"-2005 and "Focida"-2006 expeditions]. - Travaux du Muséum National d'Histoire Naturelle (Grigore Antipa) 53: 171-180.

[47] Velimirovic, V., Durovic, Z., Raicevic, M. (1992): Bug Oxycarenus lavaterae Fabricius (Lygaeidae, Heteroptera) new pest on lindens in Southern part of Montenegro. - Zastita Bilja 43: 69-72.

[48] Wachman, E., Melber, A., Deckert, J. (2007): Wanzen. Band 3. Pentatomomorpha I. Aradida, Lygaeidae, Piesmatidae, Berytidae, Pyrrhocoridae, Alydidae, Coreidae, Rhopalidae, Stenocephalidae. Die Tierwelt Deutschlands, 78. Teil. - Goecke \& Evers, Keltern.

[49] Wermelinger, B., Wyniger, D., Forster, B. (2005): Massenauftreten und erster Nachweis von Oxycarenus lavaterae (F.) (Heteroptera: Lygaeidae) auf der Schweizer Alpennordseite. - Mitteilungen der Schweizerischen Entomologischen Gesellschaft 78: 311-316.

[50] Yazıc1, G., Yildırım, E., Moulet, P. (2015): Contribution to the knowledge of the Lygaeoidea (Hemiptera, Heteroptera) fauna of Turkey. - Linzer boil. Beitr. 47(1): 969990. 